\title{
In Vitro Propagation of Drosera spp.
}

\author{
Janice L. Anthony \\ Department of Biology, Texas A\&M University, College Station, \\ TX 77843
}

Additional index words. tissue culture, micropropagation, endangered species, sundew

Carnivorous plants are being depleted from their natural environment due to large-scale collection of plants and development of sites that formerly supported carnivorous plant populations (Campbell, 1983; Juniper et al., 1989). Although there are now reputable dealers of carnivorous plants who do not collect plants from the wild, some species are already considered threatened or endangered (Ayensu and DeFilipps, 1978). If these plants are to continue to be made available to the public without danger to existing natural stands, it is imperative that alternative methods of production be investigated.

In vitro propagation of carnivorous plants is indicated because many plants may be rapidly produced from a small amount of tissue, thereby minimizing collection from natural populations. Several types of carnivorous plants have been successfully propagated in vitro, including the Venus fly trap Dionaea muscipula Ellis (M. Crehan, personal communication) and others (Adams et al., 1979a, 1979b; Carroll, 1982; Mohan Ram et al., 1972). This paper describes a simple method of propagating Drosera spp. in vitro.

The sundews, Drosera rotundifolia L, $D$. capensis L., and $D$. binata La Billardière, were chosen for this study because of their varying growth characteristics: $D$. rotundifolia has a prostrate growth habit with leaves in contact with the soil, and D. binata and $D$. capensis have upright growth. Plants were obtained from Carnivorous Gardens (Hamilton, N.Y.) and grown in $100 \%$ sphagnum under fluorescent lights (Philips 40-W AgroLite fluorescent bulbs) with a 12-h photoperiod.

Whole plants and whole leaves were sterilized in $10 \%(\mathrm{v} / \mathrm{v})$ Clorox $(0.5 \%$ sodium hypochlorite) with one drop of Tween 80 added to each $50 \mathrm{ml}$ of diluted Clorox. Tissue was sterilized for 5 min followed by three 5-min sterile distilled water rinses. Whole leaves were used as explants and were placed in $25 \times 150-\mathrm{mm}$ culture tubes on $20 \mathrm{ml}$ of medium consisting of Murashige and Skoog mineral salts and vitamins (Murashige and Skoog, 1962) supplemented with $30 \mathrm{~g}$ sucrose/liter and solidified with $8 \mathrm{~g}$ Difco agar/ liter. Medium was adjusted to $\mathrm{pH} 5.7$ before autoclaving. Because carnivorous plants normally grow in nutrient-poor areas, $1 / 2$, $1 / 4$, and $1 / 8$ normal salt and vitamin con-

Received for publication 22 July 1991. Accepted for publication 11 Mar. 1992. The cost of publishing this paper was defrayed in part by the payment of page charges. Under postal regulations, this paper therefore must be hereby marked $a d$ vertisement solely to indicate this fact. centrations (1/2 MS, 1/4 MS, and 1/8 MS, respectively) were examined in addition to full-strength medium. Dilutions of fullstrength medium containing vitamins were used for $1 / 2 \mathrm{MS}, 1 / 4 \mathrm{MS}$, and 1/8 MS. Explants were grown on media without phytohormones and on media containing BA at $0.02 \mathrm{mg} \cdot \mathrm{liter}^{-1}$ and NAA at $0.01 \mathrm{mg} \cdot \mathrm{liter}^{-1}$, according to Adams et al. (1979b). Cultures were grown at $25 \mathrm{C}$ with fluorescent lighting (as described above) under a 16-h photoperiod.

After $\approx 4$ weeks, shoots were visible on leaf explants, apparently forming directly on leaf surfaces without intermediate callus. Leaf explants grown on $1 / 2 \mathrm{MS}$ with or without hormones produced multiple plantlets that entirely covered the original leaf explant (Fig. 1A). In many cases, too many plantlets were produced to count accurately. All but one leaf explant grown on 1/2 MS and 1/4 MS produced plantlets, but more plantlets were produced on 1/2 MS. Plantlets were produced on $60 \%$ and $38 \%$ of the explants on $1 / 8 \mathrm{MS}$ and full-strength medium, respectively.

Plantlets were readily subcultured on $1 / 2$ MS without hormones. All subcultured $D$. rotundifolia and $D$. capensis plantlets produced extensive root systems after 6 to 8 weeks (Fig. 1B), in contrast to the generally weak-rooted plants found in the wild (Juniper et al., 1989). Only $10 \%$ of the D. binata plantlets rooted on medium without hormones, whereas $30 \%$ rooted on $1 / 2$ MS containing BA and NAA. About one-half of the $D$. rotundifolia and D. capensis cultures produced flowers on 1/2 MS with or without

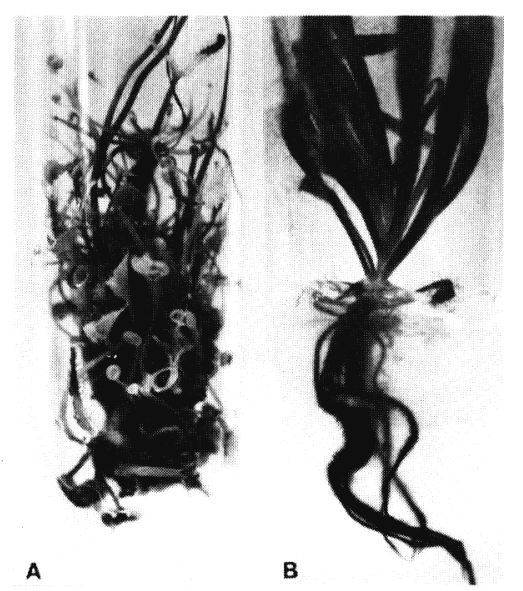

Fig. 1. (A) Numerous small plantlets forming on leaf explant of Drosera binata. (B) Extensive root system developing on culture of $D$. capensis. hormones, and $90 \%$ of the D. binata cultures produced flowers on $1 / 2$ MS containing hormones. $D$. binata cultures on medium without hormones did not produce flowers.

Plantlets were removed from culture following root development and planted in 100liter pots in $100 \%$ sphagnum or peatmoss. Pots were placed in magenta boxes (Magenta Corp., Chicago) and acclimated by gradually removing the covers, thereby reducing the relative humidity over 4 weeks. Growth conditions were the same as for cultures, and mature plants flowered and produced viable seed.

About $75 \%$ of the original cultures were contaminated. When explants were treated with $20 \%$ Clorox for 10 min or $10 \%$ Clorox for $20 \mathrm{~min}$, tissue damage was extensive and no regeneration occurred. Occasionally, cultures were contaminated in the immediate area surrounding the explant even when the tissue was dead. No clean cultures were obtained using whole plants as the tissue source.

About $95 \%$ of the original D. rotundifolia cultures were contaminated. Drosera rotundifolia has a prostrate growth habit as compared with $D$. capensis or D. binata, and it is likely that leaves in close proximity to the soil would be infested with more soil-borne organisms than leaves of plants with a more upright growth habit. Contamination problems could also be due to a symbiotic relationship that may exist between some carnivorous plants and certain fungi or bacteria that may have a role in the digestive process. After a culture appeared to be clean, contamination of subcultures was much reduced but not eliminated, indicating that microorganisms may remain in intercellular spaces in cultured plants and may occasionally be stimulated to resume growth.

\section{Literature Cited}

Adams, R.M., S.S. Koenigsberg, and R.W Langhans. 1979a. In vitro propagation of $\mathrm{Ce}$ phalotus follicularis (Australian Pitcher Plant). HortScience 14:512-513.

Adams, R.M., S.S. Koenigsberg, and R.W. Langhans. 1979b. In vitro propagation of the butterwort Pinguicula moranensis H.B.K. HortScience 14:701-702.

Ayensu, E.S. and R.A. DeFilipps. 1978. Endangered and threatened plants of the United States. Smithsonian Inst. and World Wildlife Fund, Inc. Washington, D.C.

Campbell, F.T. 1983. Carnivorous plants deserve protection. Carnivorous Plant Nwsl. 12:96-98.

Carroll, W. 1982. Tissue culture of Pinguicula Carnivorous Plant Nwsl. 11:93-96.

Juniper, B.E., R.J. Robins, and D.M. Joel. 1989 The carnivorous plants. Academic, London.

Mohan Ram, H.Y., H. Harada, and J.P. Nitsch. 1972. Studies on growth and flowering in axenic cultures of insectivorous plants: Effects of photoperiod, ethrel, morphactin and a few other growth substances and metabolic inhibitors on Utricularia inflexa. Z. Pflanzenphysiol. 68:235253.

Murashige, T. and F. Skoog. 1962. A revised medium for rapid growth and bioassays with tobacco tissue cultures. Physiol. Plant. 1:474-497. 